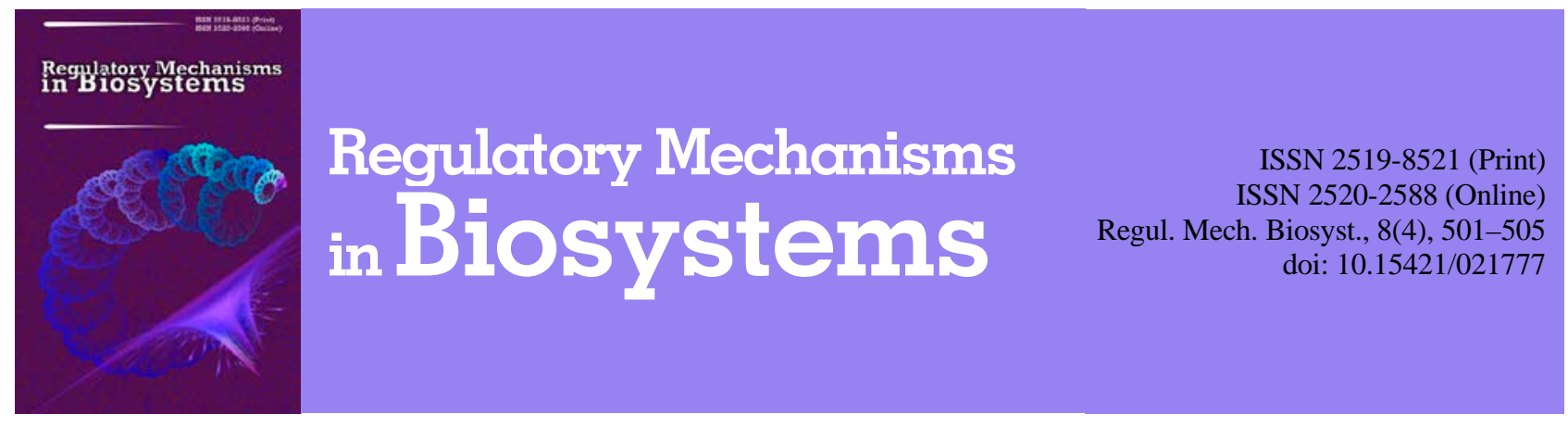

\title{
Proliferative activity of bone marrow cells of rats under the influence of biologically active substances of a medical leech
}

\author{
R. F. Aminov, A. K. Frolov \\ Zaporizhzhia National University, Zaporizhzhia, Ukraine
}

Article info

Received 02.10.2017

Received in revised form 29.10.2017

Accepted 05.11.2017

Zaporizhzhia National University, Zhukovskogo st., 66,

Zhaporizhzhia, 69600, Ukraine.

Tel.: +38-067-479-65-91

E-mail: 91_amin_91@ukr.net,

a_frolov@ukr.net

\begin{abstract}
Aminov, R. F., \& Frolov, A. K. (2017). Proliferative activity of bone marrow cells of rats under the influence of biologically active substances of a medical leech. Regulatory Mechanisms in Biosystems, 8(4), 501-505. doi:10.15421/021777
\end{abstract}

Hirudotherapy has been used in medicine since time immemorial. The advantage of this type of treatment is that the bite of a leech has a restorative effect on the entire body. The leech bites the skin and injects into the patient's blood biologically active substances that activate blood microcirculation and promote immunity. The saliva of the leech contains more than 100 substances that contribute to the spectrum of therapeutic effects. But there are no studies on the effect of hirudotherapy on the proliferation of bone marrow cells, which is ontogenetically primary in the development of myeloid and lymphoid tissues. Therefore, it is important to study the mitotic activity of bone marrow of rats at the early stages of postembryonic development against the background of influence by the leech. Female nonlinear rats, two weeks before and two weeks after mating with males, were presented each week to one hungry medical leech weighing $400 \mathrm{mg}$. The females were examined after feeding their offspring and their offspring were likewise examined on day $1,15,30,45,60$ of the experiment. The animals were kept in vivarium conditions on a standard diet in individual cages. All animals were decapitated under ether anesthesia and the number of leukocytes, the leukocyte blood count, the number of erythrocytes, hemoglobin, and the color index were examined. After that, the femurs were quickly removed and the adjacent muscles separated with a sterile gauze. We cut the epiphyses and cut along the bone. Bone marrow from the femur was flushed with a warm $\left(37^{\circ} \mathrm{C}\right)$ hypotonic $0.9 \%$ sodium citrate solution into a sterile centrifuge tube using a Pasteur pipette. The resulting cell suspension was incubated in a hypotonic solution for 10 minutes at $37^{\circ} \mathrm{C}$. The resulting suspension was centrifuged for 5 minutes at $1000 \mathrm{rpm}$ leaving only a small residue of sediment in the test tube. The cells were fixed in methyl alcohol with glacial acetic acid (three parts methyl alcohol and one part acetic acid). 3,000 cells were analyzed, among which we determined those that are in mitosis, and expressed their share. As a result of our studies, the immunomodulating effect of the saliva of the medical leech was revealed, which manifested itself in an increase in the proliferative activity of bone marrow cells, which led to an increase in the number of red blood cells, increased hemoglobin and increase in the number of leukocytes. The color index and the leukocyte blood count were within the normal limits.

Keywords: hirudotherapy; hirudology; stages of mitosis; leukocytes; erythrocyte; hemoglobin

\section{Проліферативна активність клітин кісткового мозку щурів за впливу біологічно активних речовин медичної п’явки}

\author{
Р. Ф. Амінов, О. К. Фролов
}

\section{Запорізький національний університет, Запоріжжя, Україна}

Гірудотерапія (у перекладі з латини - лікування п’явками) - один із натуротерапевтичних методів, який знайшов застосування у сучасній медицині. У слині медичної п'явки виявлено понад 100 біологічно активних речовин, які викликають широкий спектр профілактичнолікувальних ефектів. Досліджено вплив біологічно активних речовин медичної п’явки Hirudo verbana (Carena, 1820) на мітотичну активність кісткового мозку та гематологічні показники крові: загальну кількість лейкоцитів, еритроцитів, гемоглобін, кольоровий показник i лейкоцитарну формулу крові самок нелінійних щурів після вигодовування приплоду, яким за два тижні до парування та два тижні після приставляли по одній медичній п’явці кожного тижня (масою 400 мг), таку саму процедуру робили їх приплоду на 1, 15, 30, 45, 60-ту добу. У тварин брали кров і досліджували їі показники. Стегнові кістки швидко очищали від прилеглих м'язів. Відрізали епіфізи та розрізали уздовж кістки, вимиваючи кістковий мозок теплим гіпотонічним $0,9 \%$ розчином цитрату натрію у стерильну пробірку. Отриману клітинну суспензію інкубувати в гіпотонічному середовищі 10 хв за температури $37^{\circ} \mathrm{C}$. Центрифугували отриману суспензію протягом 5 хв за 1000 об./хв і залишали небагато осаду у пробірці. Клітини фіксували у метиловому спирті з крижаною оцтовою кислотою. За 12 год. фіксації тричі змінювали фіксатор із проміжним ресуспензуванням осаду та наступним центрифугуванням. В останньому фіксаторі осад ресуспензували та наносили на чисто вимите предметне скло. Скло швидко проводили через полум’я пальника, щоб фіксатор запалав, але не допускали 
перегрівання. Аналізували 3000 клітин, серед яких визначали такі, що перебувають у мітозі. Виявлено імуномоделювальну дію слини медичної п’явки, відмічено тенденцію до збільшення мітотичної активності клітин кісткового мозку у самок щурів. Аналіз приплоду достовірного підвищення проліферативної активності клітин кісткового мозку не виявив. Зростання мітотичної активності кісткового мозку в самок щурів зумовило збільшення кількості еритроцитів, підвищення концентрації гемоглобіну, кількості лейкоцитів. Кольоровий показник і лейкоцитарна формула крові залишились у межах норми. Отримані результати можуть свідчити про вплив біологічно активних речовин слини $H$. verbana на механізми позитивної регуляції онтогенезу.

Ключові слова: гірудотерапія; гірудологія; стадії мітозу; лейкоцити; еритроцити; гемоглобін

\section{Вступ}

Сучасна фармакологія, безумовно, досягла великих успіхів, але часто виявляють побічні дії від ії використання у лікуванні низки захворювань. 3’явилася ціла серія хвороб, які звуть лікарськими (Matvjejeva et al., 2011). Тому дослідники все більше починають вивчати та досліджувати різні натуротерапевтичні методи впливу на організм тварини та людини, один 3 яких - гірудотерапія. Нині вона набуває все більшого значення (Abdullah et al., 2012). Гірудотерапію широко застосовують у медицині (Mumcuoglu et al., 2004; Hullett et al., 2007; Abbas Zaidi et al., 2011) та ветеринарії (Popova, 2003; Frolov et al., 2010; Sobczak and Kantyka, 2014). Перевага цього виду лікування в тому, що укус п'явки дає відновлювальний ефект на весь організм (Zharov, 2003; Savinov, 2004; Kamenev and Baranovskij, 2010). П'явка прокушує шкіру та вводить у кров пацієнта біологічно активні речовини (Meriaux et al., 2011; Abdualkader et al., 2013; Frolov and Litvinenko, 2014), які активізують мікроциркуляцію крові та сприяють підвищенню імунітету (Aminov and Frolov, 2015; Frolov and Litvinenko, 2015). Слина п'явки містить понад 100 речовин, що сприяють спектру терапевтичних ефектів (Eldor et al.,1996; Pospelova and Barnaulov, 2010; Hildebrandt and Lemke, 2011; Koeppen et al., 2014). Тому гірудотерапію та фармакологічні препарати на основі слини п'явки ефективно використовують із метою лікування та профілактики в дерматології (Kumar, 2012), кардіології (Isahanjan and Arutjunjan, 1991), оториноларингології (Flaum and Shahov, 2008), травматології (Michalsen et al., 2008) та в інших сферах медицини. У практиці зарубіжних країн медичних п’явок використовують головним чином під час трансплантацій із метою усунення венозного застою (конгестіi) (Chepeha et al., 2002; Frodel et al., 2004; Bank et al., 2008).

Дослідження морфофізіологічних змін у кіз після курсів гірудологічних приставок у період їх роздоювання показали у них збільшення маси тіла та молочності без ускладнення маститом, а в репродуктивний період відмічено 100\% запліднення iз народженням двійнят зі збільшеною вагою (Frolov et al., 2010). Під час дослідів, які проводили на коровах, гірудологічні приставки сприяли пришвидшеній післяпологовій реабілітації, зворотній інволюції репродуктивних органів до фізіологічного стану (Popova, 1999).

У попередніх дослідах доведено, що слина медичної п'явки після гірудотерапії стимулює морфогенетичні процеси, опосередковані в основному через фактори імунної системи (підвищення фізіологічних параметрів тіла, стимуляція мієлоїдної та лімфоїдної тканин (селезінки та тимусу) i, як наслідок, збільшення розмірів органів) (Aminov et al., 2016), посилення функціональної активності нейтрофілів крові (Zharov, 2003; Savinov, 2004; Kamenev and Baranovskij, 2010; Aminov and Frolov, 2016), але відсутні дослідження впливу гірудотерапії на проліферацію клітин кісткового мозку - середовища розвитку мієлоїдних та лімфоїдних тканин.

Тому мета наших досліджень - виявити мітотичну активність кісткового мозку щурів на ранніх етапах постембріонального розвитку на фоні гірудологічного впливу.

\section{Матеріал і методи досліджень}

Дорослим самкам нелінійних щурів масою 150-200 г два тижні до парування та два тижні після робили приставки по одній голодній медичній п’явці Hirudo verbana (Carena, 1820) кожного тижня масою 400 мг (4 приставки). Тварин розподіляли на дві групи: перша (дослідна) група тварин за впливу біологічно активних речовин $H$. verbana; друга (контрольна) група - без втручань. Досліджували самок після вигодовування приплоду, а також приплід у динаміці на 1, 15, 30, 45, 60-ту добу. Експериментальні дослідження виконані з дотриманням міжнародних принципів Європейської конвенції про захист хребетних тварин, яких використовують для дослідних та інших наукових цілей, згідно із Законом України від 21.02.2006 p. № 3447-IV «Про захист тварин від жорстокого поводження» та згідно 3 етичними нормами та правилами роботи 3 лабораторними тваринами. Тварин утримували в умовах віварію на стандартному раціоні в індивідуальних клітках (Zapadnjuk et al., 1983). Усього в експерименті задіяно 40 нелінійних самок щурів та 200 екземплярів приплоду.

Усіх тварин декапітували під ефірним наркозом і досліджували кількість лейкоцитів, лейкоцитарну формулу крові, кількість еритроцитів, гемоглобін і кольоровий показник (Berkalo et al., 2003). Після цього швидко вилучали стегнові кістки, очищали їх від прилеглих м'язів за допомогою стерильної марлі. Відрізали епіфізи та розрізали вздовж кістки. Кістковий мозок зі стегнової кістки вимивали теплим $\left(37^{\circ} \mathrm{C}\right)$ гіпотонічним $0,9 \%$ розчином цитрату натрію у стерильну центрифужну пробірку, використовуючи для цієї мети пастерівську піпетку.

Шматочки кісткового мозку подрібнювали піпетуванням. Отриману клітинну суспензію інкубували в гіпотонічному середовищі 10 хв за температури $37^{\circ} \mathrm{C}$. Суспензію центрифугували протягом 5 хв за 1000 об./хв, залишаючи небагато осаду у пробірці (тонкий шар на дні пробірки). Обережно відсмоктували піпеткою всю надосадову рідину. Клітини фіксували у метиловому спирті $з$ крижаною оцтовою кислотою (три частини метилового спирту та одна частина оцтової кислоти). Для цього до осаду обережно доливали охолоджений фіксатор (близько 2 мл), намагаючись не розбити осад. Загальний час фіксації 12 год. За цей час тричі змінювали фіксатор, із проміжним ресуспензуванням осаду та наступним центрифугуванням. В останньому фіксаторі осад ресуспензували та наносили на чисто вимите предметне скло (скло тримали у дистильованій воді в холодильнику) 2-3 краплини суспензії клітин у фіксаторі. Скло швидко проводили через полум'я пальника, щоб фіксатор запалав, але не допускали перегрівання. Добре висушені препарати фарбували методом Романовського - Гімза 40 хв, після чого промивали у дистильованій воді та диференціювали в підкисленій $\mathrm{HCl}$ воді. Аналізували 3000 клітин, серед яких визначали ті, що перебували в мітозі, та виражали їх частку в проміле (Bogdanova, 2016).

Статистичну обробку даних здійснювали за допомогою комп'ютерної програми SPSS v.21,0 (IBM SPSS Statistics, USA). Вибіркові параметри, наведені в таблиці, мають такі позначення: $\mathrm{x}$ - вибіркове середнє, SE - стандартна помилка середнього. Достовірність різниці показників оцінювали за допомогою F-критерію Фішера. Вірогідною вважали різницю між вибірками $\mathrm{P}<0,05$.

\section{Результати}

Під час дослідження проліферативної активності клітин кісткового мозку відмічали тенденцію до збільшення мітотичного індексу в дослідної групи самок щурів (на $32,6 \%, \mathrm{P}<0,07$, табл. 1). У їх приплоду достовірне підвищення проліферативної активності клітин кісткового мозку спостерігали на 15-ту 
(на $29,1 \%, \mathrm{P}<0,05$ ) та 45-ту добу (на $32,2 \%, \mathrm{P}<0,01$ ), із тенденцією до збільшення на 1 -шу (на 50,9\%, Р $<0,06$ ), 30 -ту (на 42,0\%, $\mathrm{P}<0,07$ ) та 60 -ту добу (на $25,2 \%, \mathrm{P}<0,08$ ) порівняно 3 контрольною групою (табл. 1). У результаті підвищення мітотичного індексу відмічали збільшення еритроцитарних і лейкоцитарних показників периферичної крові дослідних самок та їх приплоду (табл. 2). У самок тенденція до збільшення кількості еритроцитів (на $24,4 \%, \mathrm{P}<0,08$ ), гемоглобіну (на $16,1 \%, \mathrm{P}<0,09$ ), лейкоцитів (на $54,2 \%, \mathrm{P}<0,06$ ) зареєстрована порівняно 3 контрольною групою. Адекватні позитивні зрушення гематологічних показників спостерігали також у приплоду. Причому найбільші зміни реєстрували до 30-ї доби життя (табл. 2). Збільшення кількості лейкоцитів у дослідної групи щурів відмічали без істотних змін у лейкоцитарній формулі крові (табл. 3).
Таблиця 1

Мітотична активність кісткового мозку самок щурів та їх приплоду за впливу біологічно активних речовин $H$. verbana (\%o, $\mathrm{x} \pm \mathrm{SE}, \mathrm{n}=20)$

\begin{tabular}{lcc}
\hline \multicolumn{1}{c}{ Доба онтогенезу } & Контроль & $\begin{array}{c}\text { Вплив слини } \\
\text { H. verbana }\end{array}$ \\
\hline 220 -та (самки) & $14,84 \pm 0,32$ & $22,24 \pm 1,06$ \\
1 -ша & $14,33 \pm 0,30$ & $28,90 \pm 0,44$ \\
15 -та & $15,09 \pm 1,14$ & $21,53 \pm 1,16^{*}$ \\
30 -та & $9,17 \pm 0,48$ & $16,23 \pm 1,26$ \\
45 -та & $9,05 \pm 0,53$ & $14,16 \pm 0,16^{* *}$ \\
60 -та & $10,96 \pm 0,54$ & $14,38 \pm 0,43$ \\
\hline
\end{tabular}

Примітка: *- $\mathrm{P}<0,05$; ** $-\mathrm{P}<0,01$ порівняно 3 контролем.

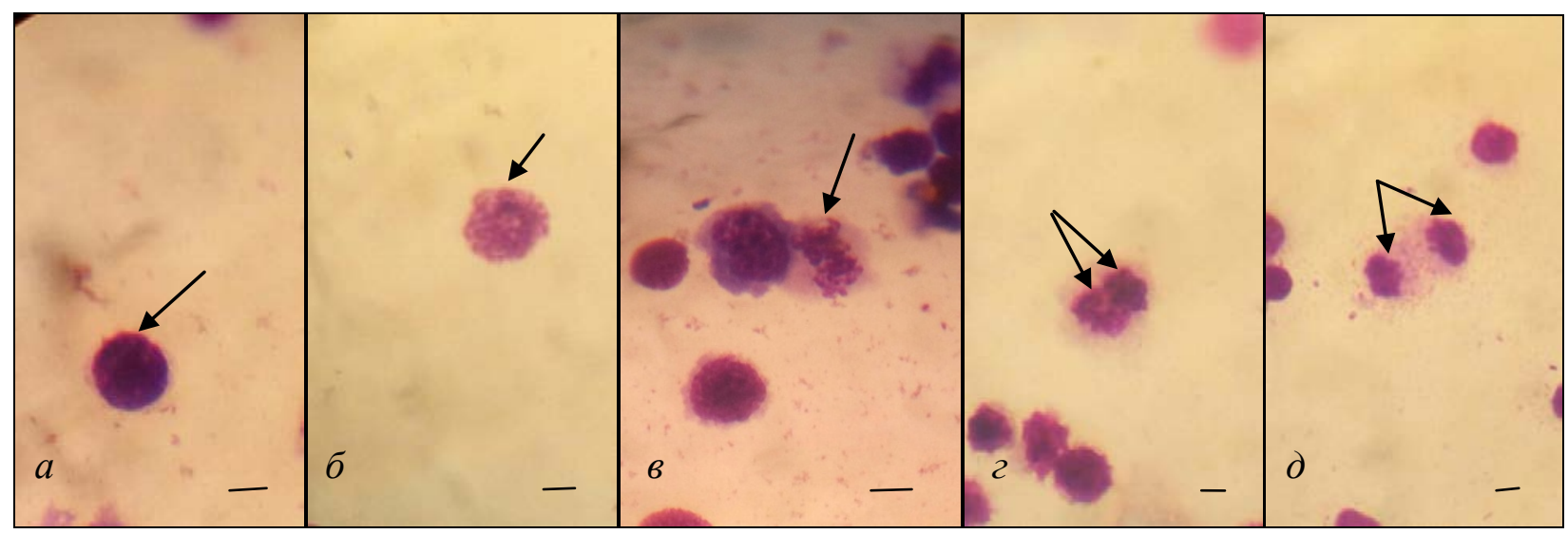

Рис. 1. Стадії мітозу: $a$ - інтерфаза, $\sigma$ - профаза, $в$ - метафаза, 2 - анафаза, $\partial$ - телофаза (чорними стрілками помічена клітина у стадії мітозу); довжина бара - 10 мкм; забарвлення за методом Романовського - Гімза

Таблиця 2

Кількість лейкоцитів і еритроцитів, гемоглобін, кольоровий показник у самок щурів та їх приплоду за впливу біологічно активних речовин $H$. verbana $(\mathrm{x} \pm \mathrm{SE}, \mathrm{n}=20)$

\begin{tabular}{|c|c|c|c|c|c|}
\hline \multirow{2}{*}{$\begin{array}{c}\text { Доба } \\
\text { онтогенезу }\end{array}$} & \multirow{2}{*}{ Група тварин } & \multicolumn{4}{|c|}{ Показники } \\
\hline & & лейкоцити, $\times 10^{9} / л$ & еритроцити, $\times 10^{12} /$ л & гемоглобін, г/л & кольоровий показник, \% \\
\hline 220-та & контроль & $5,02 \pm 0,25$ & $7,08 \pm 0,40$ & $136,1 \pm 4,8$ & $0,58 \pm 0,04$ \\
\hline (самки) & вплив слини H. verbana & $8,16 \pm 0,66$ & $8,78 \pm 0,29$ & $158,4 \pm 3,6$ & $0,54 \pm 0,02$ \\
\hline \multirow{2}{*}{ 1-ша } & контроль & $5,85 \pm 0,35$ & $2,84 \pm 0,10$ & $62,7 \pm 2,7$ & $0,66 \pm 0,12$ \\
\hline & вплив слини H. verbana & $7,68 \pm 0,55$ & $3,11 \pm 0,22$ & $83,8 \pm 2,7$ & $0,81 \pm 0,10$ \\
\hline \multirow{2}{*}{ 15-та } & контроль & $6,74 \pm 0,54$ & $4,16 \pm 0,18$ & $79,5 \pm 1,6$ & $0,57 \pm 0,06$ \\
\hline & вплив слини H. verbana & $7,87 \pm 0,51^{* * *}$ & $3,69 \pm 0,29$ & $86,2 \pm 3,5^{*}$ & $0,70 \pm 0,01$ \\
\hline \multirow{2}{*}{ 30-та } & контроль & $3,39 \pm 0,30$ & $3,79 \pm 0,13$ & $90,9 \pm 3,1$ & $0,72 \pm 0,05$ \\
\hline & вплив слини H. verbana & $5,43 \pm 0,29$ & $4,76 \pm 0,22 * *$ & $102,0 \pm 3,4$ & $0,64 \pm 0,04$ \\
\hline \multirow{2}{*}{ 45-та } & контроль & $6,81 \pm 0,51$ & $5,20 \pm 0,14$ & $143,2 \pm 5,4$ & $0,83 \pm 0,09$ \\
\hline & вплив слини H. verbana & $7,12 \pm 0,31$ & $5,07 \pm 0,33$ & $140,5 \pm 6,1$ & $0,83 \pm 0,08$ \\
\hline \multirow{2}{*}{ 60-та } & контроль & $7,29 \pm 0,45$ & $6,65 \pm 0,19$ & $155,1 \pm 5,7$ & $0,70 \pm 0,06$ \\
\hline & вплив слини H. verbana & $8,23 \pm 0,45$ & $6,46 \pm 0,20$ & $153,3 \pm 5,0$ & $0,71 \pm 0,05$ \\
\hline
\end{tabular}

Примітка: *- $\mathrm{P}<0,05 ; * *-\mathrm{P}<0,01$; *** $-\mathrm{P}<0,001$ порівняно 3 контролем.

Таблиця 3

Лейкоцитарна формула крові самок щурів та їх приплоду за впливу біологічно активних речовин $H$. verbana $(\mathrm{x} \pm \mathrm{SE}, \mathrm{n}=20)$

\begin{tabular}{|c|c|c|c|c|c|c|c|}
\hline \multirow{3}{*}{$\begin{array}{c}\text { Доба } \\
\text { онтогенезу }\end{array}$} & \multirow{3}{*}{ Група тварин } & \multicolumn{6}{|c|}{ Лейкоцитарна формула крові, \% } \\
\hline & & \multicolumn{3}{|c|}{ нейтрофіли } & \multirow{2}{*}{ лімфоцити } & \multirow{2}{*}{ моноцити } & \multirow{2}{*}{ еозинофіли } \\
\hline & & паличко-ядерні & сегменто-ядерні & загальний відсоток & & & \\
\hline \multirow{2}{*}{$\begin{array}{c}\text { 220-та } \\
\text { (самки) }\end{array}$} & контроль & $8,01 \pm 0,29$ & $14,20 \pm 1,42$ & $22,41 \pm 1,02$ & $70,09 \pm 1,48$ & $7,40 \pm 0,88$ & $0,30 \pm 0,02$ \\
\hline & вплив слини H. verbana & $9,61 \pm 0,22$ & $13,96 \pm 1,02$ & $23,57 \pm 1,31$ & $70,51 \pm 1,64$ & $5,46 \pm 0,22$ & $0,46 \pm 0,06$ \\
\hline \multirow{2}{*}{ 1-ша } & контроль & $8,68 \pm 0,46$ & $43,29 \pm 2,87$ & $51,97 \pm 1,29$ & $46,63 \pm 2,39$ & $1,25 \pm 0,01$ & $0,15 \pm 0,01$ \\
\hline & вплив слини H. verbana & $9,92 \pm 0,87$ & $41,95 \pm 2,99$ & $51,87 \pm 2,33$ & $46,78 \pm 3,02$ & $1,18 \pm 0,19$ & $0,17 \pm 0,02$ \\
\hline \multirow{2}{*}{$15-$-та } & контроль & $4,95 \pm 0,65$ & $16,62 \pm 0,88$ & $21,57 \pm 1,22$ & $76,95 \pm 1,62$ & $1,31 \pm 0,13$ & $0,17 \pm 0,02$ \\
\hline & вплив слини H. verbana & $5,87 \pm 0,67$ & $14,22 \pm 1,54$ & $20,09 \pm 1,44$ & $78,54 \pm 2,32$ & $1,19 \pm 0,10$ & $0,18 \pm 0,01$ \\
\hline \multirow{2}{*}{ 30-та } & контроль & $5,10 \pm 0,29$ & $11,93 \pm 1,42$ & $17,00 \pm 1,02$ & $81,87 \pm 1,80$ & $0,47 \pm 0,02$ & $0,63 \pm 0,12$ \\
\hline & вплив слини H. verbana & $4,81 \pm 2,11$ & $15,97 \pm 2,06$ & $20,63 \pm 1,34$ & $78,98 \pm 2,87$ & $0,15 \pm 0,01$ & $0,09 \pm 0,01$ \\
\hline \multirow{2}{*}{ 45-та } & контроль & $2,78 \pm 0,34$ & $10,42 \pm 0,45$ & $13,01 \pm 1,32$ & $85,86 \pm 1,36$ & $1,24 \pm 0,12$ & $0,08 \pm 0,01$ \\
\hline & вплив слини H. verbana & $6,43 \pm 0,77$ & $11,53 \pm 0,98$ & $17,96 \pm 1,11$ & $81,40 \pm 1,72$ & $0,37 \pm 0,02$ & $0,17 \pm 0,02$ \\
\hline \multirow{2}{*}{ 60-та } & контроль & $3,64 \pm 0,38$ & $8,20 \pm 0,36$ & $11,84 \pm 0,97$ & $86,68 \pm 0,67$ & $1,39 \pm 0,15$ & $0,09 \pm 0,01$ \\
\hline & вплив слини H. verbana & $3,70 \pm 0,33$ & $12,28 \pm 0,97$ & $16,18 \pm 0,87$ & $82,90 \pm 2,00$ & $1,04 \pm 0,01$ & $0,08 \pm 0,02$ \\
\hline
\end{tabular}




\section{Обговорення}

Дослідження продемонструвало стимулювальний вплив біологічно активних речовин слини медичної п'явки на гістогенетичні реакції самок щурів та їх потомства, які проявлялися підвищенням мітотичної активності та гематологічних показників крові.

Приплід піддавався впливу тільки в преембріональний і ембріональний періоди розвитку. Отже, такий пролонгований ефект від біологічно активних речовин слини медичної п’явки, можливо, стає наслідком різних механізмів, за рахунок власних компонентів слини медичної п’явки, які частково адсорбуються до закладання тканин приплоду, частково поступаючи у рециркуляцію організму самок щурів, здійснюючи регуляцію гістогенезу. Подібні експериментальні дані описані під час дослідження впливу біологічно активних речовин слини медичної п’явки на дрібній (Frolov et al., 2010) і великій рогатій худобі (Popova and Petrov, 1999; Demidchik, 2001; Romanova et al., 2008), домашніх хребетних тваринах (Canpolat and Sağlam, 2004; Krjachko and Lukojanova, 2009; Sobczak, 2014), але без дослідів їх приплоду.

Збільшення кількості лейкоцитів у дослідної групи щурів відмічали без істотних змін лейкоцитарної формули крові порівняно $з$ контролем. Цей факт свідчить про гомеостатичний вплив біологічно активних речовин слини медичної п'явки на гематологічний гістогенез (Meriaux, 2011; Koeppen, 2014; Mumcuoglu, 2014). Можна передбачити, що у подальшому розвитку онтогенезу в дослідної групи приплоду не будуть спостерігатись відхилення від фізіологічних меж. Подібні дані описували інші автори, але мітотичну активність не було досліджено (Mineo, 2004; Frodel, 2004; Hullett, 2007). Також описано вплив біологічно активних речовин на гомеостаз (Zharov, 2003; Savinov, 2004; Kamenev and Baranovskij, 2010). Ми вперше дослідили та виявили гірудологічний вплив не тільки на дорослих тваринах, а і на їх приплоді.

\section{Висновки}

Приставки $H$. verbana самкам протягом двох тижнів до парування та двох тижнів після нього сприяють підвищенню проліферативної активності кісткового мозку щурів та їх приплоду. Адекватне підвищенню мітотичного індексу клітин кісткового мозку збільшення еритроцитарних показників (кількість еритроцитів і гемоглобін) і лейкоцитарних показників (кількість лейкоцитів). Лейкоцитарна формула крові залишається без суттєвих змін. Отримані результати мають прикладне значення для вивчення можливостей механізмів регуляції онтогенезу за впливу біологічно активних речовин слини H. verbana.

\section{References}

Abdualkader, A. M., Ghawi, A. M., Alaama, M., Awang, M., \& Merzouk, A (2013). Leech therapeutic applications. Indian Journal of Pharmaceutical Sciences, 75(2), 127-137.

Abdullah, S., Dar, M. L., Rashid, A., \& Tewari, A. (2012). Hirudotherapy. Leech therapy: Applications and indications in surgery. Archives of Clinical and Experimental Surgery, 1(3), 172-180.

Aminov, R. F., \& Frolov, O. K. (2015). Vplyv biologichno aktyvnyh rechovyn sol'ovogo ekstraktu medychnoi' p'javky na fagocytarnu aktyvnist' nejtrofiliv i cytomorfometrychni zminy limfocytiv krovi ljudyny u kul'turi [Influence of biologically active substances in the salt extract of the medicinal leech on phagocytic activity of neutrophils and cytomorphometric changes of blood lymphocytes in culture]. Naukovyj Visnyk Chernivec'kogo Universytetu. Biologija, 7(1), 108-112 (in Ukrainian).

Aminov, R. F., \& Frolov, O. K. (2016). Fagocytarna ta metabolichna aktyvnist' nejtrofiliv shhuriv na rannih etapah postembrional'nogo rozvytku za vplyvu biologichno aktyvnyh rechovyn sol'ovogo ekstraktu Hirudo verbana [Phagocytic and metabolic activity of neutrophils of rats in the early stages of post-embryonic development under the influence of biologically active substances of the salt extract of Hirudo verbana]. Visnyk of Dnipropetrovsk University. Biology, Medicine, 7(2), 96-100 (in Ukrainian).
Aminov, R. F., Frolov, A. K., \& Fedotov, E. R. (2016). The impact of fetal load of biologically active substances of Hirudo verbana saline extract antigens on the morphometric and hematologic parameters of rats in the early stages of post-embryonic development. Immunopathology, Allergology, Infectology, 4, 6-11.

Bank, J., Zilinsky, Y., Haik, J., Winkler, E., \& Goldan, O. (2008). Medicinal leech fixation in precarious locations. Reconstructive Microsurgery, 24, 67-68.

Berkalo, L. V. (2003). Metody klinichnyh ta eksperymental'nyh doslidzhen' v medycyni [Methods of clinic eksperimentalnih dozen in charity fund medical]. Polimet, Poltava (in Ukrainian).

Bogdanova, M. S. (2016). Kletochnye kul'tury [Cell cultures]. Politehn, Saint Petersburg (in Russian).

Canpolat, I., \& Sağlam, N. (2004). Treatment of diffuse hematoma in a dog with the medicinal leech, Hirudo medicinalis. Doğu Anadolu Bölgesi Araştırmaları, 2(2), 97-99.

Chepeha, D. B., Nussenbaum, B., Bradford, C. R., \& Teknos, T. N. (2002). Leech therapy for patients with surgically unsalvageable venous obstruction after revascularized free tissue transfer. Archives of Otolaryngology Head and Neck Surgery, 128, 960-965.

Demidchik, L. G. (2001). Girudoterapija pri skrytom mastite korov [Hirudotherapy with hidden cow mastitis]. Veterinarija, 2, 441 (in Russian).

Eldor, A., Orevi, M., \& Rigbi, M. (1996). The role of the leech in medical therapeutics. Blood Reviews, 10, 201-209.

Flaum, R. A., \& Shahov, A. V. (2008). Primenenie girudorefleksoterapii v lechenii pacientov s zabolevanijami vnutrennego uha [Application girudorefleksoterapii in the treatment of patients with diseases of the inner ear]. Medicinskij Al'manah, 2, 63-65 (in Russian).

Frodel, J., Barth, P., \& Wagner, J. (2004). Salvage of partial facial soft tissue avulsions with medicinal leeches. Archives of Otolaryngology Head and Neck Surgery, 131, 934-939.

Frolov, A. K., \& Litvinenko, R. A. (2014). Reaction of patients' lymphocytes' blast-transformation in blood, stimulated by plant mitogens and annelid antigens at hirudotherapy. Immunopatologija, Allergologija, Infektologija, 3, $10-13$.

Frolov, A. K., \& Litvinenko, R. A. (2015). Basic morphofunctional features of pharmaceutic leech (Hirudo verbana Carena, 1820) tissues in various forms of response after hirudotherapeutic procedures. Annals of Parasitology, 61(1), 27-35.

Frolov, A. K., Kopejka, V. V., \& Fedotov, E. R. (2010). Vlijanie girudoterapii na fiziologicheskie pokazateli u koz [The impact of treatment on physiological parameters in goats]. Zhivotnovodstvo Ukrainy, 7, 7-10 (in Russian).

Hildebrandt, J. P., \& Lemke, S. (2011). Small bite, large impactsaliva and salivary molecules in the medicinal leech, Hirudo medicinalis. Naturwissenschaften, 98(12), 995-1008.

Hullett, J. S., Spinnato, G. G., \& Zi, V. (2007). Treatment of an ear laceration with adjunctive leech therapy: A case report. Journal of Oral and Maxillofacial Surgery, 65, 2112-2114.

Isahanjan, G. S., \& Arutjunjan, V. M. (1991). Medicinskie pijavki ih lechebnoe primenenie v terapevticheskoj klinike [Medical leeches: their therapeutic use in a therapeutic clinic]. Terapevticheskij Arhiv, 63(8), 110-112 (in Russian).

Kamenev, O. J., \& Baranovskij, A. J. (2010). Lechenie pijavkami - teorija i praktika girudoterapii [Treatment by leeches: Theory and practice hirudotherapy]. Ves', Saint Petersburg (in Russian).

Koeppen, D., Aurich, M., \& Rampp, T. (2014). Medicinal leech therapy in pain syndromes: A narrative review. Wiener Medizinische Wochenschrift, 164(5-6), 95-102.

Krjachko, O. V., \& Lukojanova, L. A. (2009). Vlijanie girudoterapii na nekotorye gematologicheskie i biohimicheskie pokazateli pri intoksikacionnom sindrome u sobak [The influence of hirudotherapy on some hematologic and biochemical indices in case of intoxication syndrome in dogs]. Veterinarnaja Praktika, 1, 65-68 (in Russian).

Kumar, S. A. (2012). Anti inflammatory effect of leech therapy in the patients of psoriasis. Journal of Pharmaceutical and Scientific Innovation, 1(1), 71-74.

Matvjejeva O. V., Viktorov O. P., Blihar V. J., Puhlyk B. M., Chop’jak, V. V., Jajchenja, V. P., Logvina, I. O., \& Bykanova, I. I. (2011). Do pytannja klasyfikacii' pobichnyh reakcij likars'kyh zasobiv ta pidhodiv do i'h dyferenciacii' (bibliografichnyj ogljad) [To the question of classification of adverse reactions of medicinal products and approaches to their differentiation (bibliographic review)]. Ukrai'ns'kyj Medychnyj Chasopys, 82, 78-84 (in Ukrainian).

Meriaux, C., Arafah, K., Tasiemski, A., Wisztorski, M., Bruand, J., Boidin-Wichlacz, C., Desmons, A., Debois, D., Laprévote, O., Brunelle, A., Gaasterland, T., Macagno, E., Fournier, I., \& Salzet, M. (2011). Multiple changes in peptide and lipid expression associated with regeneration in the nervous system of the medicinal leech. PLoS ONE, 6(4), e18359.

Michalsen, A., Lüdtke, R., Cesur, O., Afra, D., Musial, F., Baecker, M., Fink, M., \& Dobos, G. J. (2008). Effectiveness of leech therapy in women with symptomatic arthrosis of the first carpometacarpal joint: A randomized controlled trial. Pain, 137(2), 452-459. 
Mineo, M., Jolley, T., \& Rodriguez, G. (2004). Leech therapy in penile replantation: A case of recurrent penile selfamputation. Urology, 63, 981-983.

Mumcuoglu, K. Y. (2014). Recommendations for the use of leeches in reconstructive plastic surgery. Evidence-Based Complementary and Alternative Medicine, 1, 1-7.

Popova, L. K., \& Petrov, A. N. (1999). Girudoakupunktura pri subklinicheskom mastite u korov [Hirurdoacupuncture with subclinical mastitis in cows]. Veterinarija, 10, 23-24 (in Russian).

Pospelova, M. L., \& Barnaulov, O. D. (2010). Effects of hirudotherapy on intravascular thrombosis activation in different groups of patients with cerebrovascular pathologies. Aktuelnosti iz Neurologije, Psihijatrije i Graničnih Područja, 18(3), 27-32.

Romanova, E. M., Klimina, O. M., \& Kozlova, L. A. (2008). Primenenie girudoterapii i girudoakupunktury pri subklinicheskoj forme mastita u korov [The use of hirudotherapy and hirudoacupuncture in the subclinical form of mastitis in cows]. Veterinarnyj Vrach, 4, 35-37 (in Russian).

Savinov, V. A. (2004). Girudoterapija [Hirudotherapy]. Medicina, Moscow (in Russian)

Sobczak, N., \& Kantyka, M. (2014). Hirudotherapy in veterinary medicine. Annals of Parasitology, 60(2), 89-92.

Zaidi, S. M., Jameel, S. S., Zaman, F., Jilani, S., Sultana, A., \& Khan, S. A. (2011) A systematic overview of the medicinal importance of sanguivorous leeches. Alternative Medicine Review, 16(1), 59-65.

Zapadnjuk, I. P., Zapadnjuk, V. I., \& Zaharija, E. A. (1983). Laboratomye zhivotnye. Razvedenie, soderzhanie, ispol'zovanie v jeksperimente [Laboratory animals. Breeding, keeping, use in the experiment]. Vishha Shkola, Kiev (in Russian).

Zharov, D. G. (2003). Sekrety girudoterapii ili kak lechit'sja pijavkami [Secrets of treatment or how to treat leeches]. Feniks, Rostov (in Russian). 